Article History:

Submitted:

11 July 2021

Reviewed:

18 December 2021

Edited:

21 December 2021

28 December 2021

Accepted:

28 December 2021

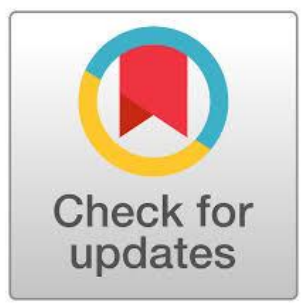

\section{Exploring Teachers' and Students' Attitudes towards English Language Large Classes at Herat University, Afghanistan}

\author{
Ahmad Fawad Kakar, Kawita Sarwari ${ }^{*}$ \\ Herat University, Afghanistan \\ ${ }^{*}$ Corresponding author's email: \\ kawita.sarwari65@gmail.com
}

DOI: https://doi.org/10.18196/ftl.v7i1.12281

\begin{abstract}
This study is qualitative research that seeks to investigate the large class teaching challenges and the instructors' coping strategies through the perspectives of five English language instructors of the English Department of Herat University. Furthermore, the perspectives of ten juniors and seniors of the English Department of Herat University on large EFL classes are also explored. The data collected through face-to-face semi-structured interviews were analyzed thematically. In other words, the data were divided into major and sub-themes, considering the study's theoretical framework-Kumaravadevelu's post-method pedagogy- and the research questions. The findings indicated that challenges, such as multi-level students, under-resourced context, a large number of students, giving feedback, assessing students, classroom management, and students' engagement, are the challenges behind large classes in Afghanistan. Further, reducing the number of students, providing teachers with capacity-building programs and teaching resources are also discussed.
\end{abstract}

Keywords: classroom management; feedback; large classes; student engagement 
Journal of Foreign Language Teaching and Learning

Volume 7, No. 1, January 2022

Available online at: https://journal.umy.ac.id/index.php/FTL/issue/view/833

e-ISSN: 2580-2070, p-ISSN: 2527-7650

\section{Introduction}

English language teachers in Afghanistan, a developing country with a traditional-based (lecture-based, no/less technology integration) education system, consider teaching the English language effectively in large, multi-level, and under-resourced classes a serious challenge. A large number of students (50-100) in one class, coming from different backgrounds and levels, lack of facilities such as comfortable and well-equipped classrooms, and high level of teaching materials are the challenges of large classes in Afghanistan. According to Shamin (1993), all the challenges mentioned above make teaching and learning a language difficult. Since English language teachers are expected to pay more attention to individuals' oral communication besides other skills such as writing, meeting this expectation in large, multi-level classes is difficult. In addition, class management is another serious problem of large classes in Afghan Universities; students who sit in the back can easily be neglected and receive less attention (Yu \& Lee, 2016). Generally, less effective learning, lecture-based teaching, lack of student participation, use of mother tongue, lack of group work, physically uncomfortable learning space, assessment, and receiving and giving feedback are all challenges in large classes (Sarwar, 2001).

Although some studies have focused on teaching in large, multi-level classes in different contexts, particularly under developing and developing countries, more research is needed, especially in the context of Afghanistan, where, unfortunately, because of several decades of war and conflicts, there are less or no publications addressing the large class size-related issues from both teachers and students' perspectives. Moreover, both Afghan EFL teachers and students complain about weak management in large English classes, students' engagement, monitoring and controlling the class, providing students with feedback, providing level-appropriate teaching materials, and many more. Therefore, there is a need to deeply study the effect of large class sizes on the quality of teaching in large classes. For this reason, this study greatly contributes to the body of literature related to large English language class sizes in general and in the context of Afghanistan. Furthermore, investigating the students' attitudes of the English Department of Herat University related to the challenges of learning in large multi-level classes informs teachers of what students think about learning in large classes, which significantly contributes to the field. The current study also may support future research activities related to the English language teaching and learning process in the Afghan context. 
Journal of Foreign Language Teaching and Learning

Volume 7, No. 1, January 2022

Available online at: https://journal.umy.ac.id/index.php/FTL/issue/view/833

e-ISSN: 2580-2070, p-ISSN: 2527-7650

In this study, three questions tended to be answered: (1) What are the main challenges of large, multi-level English language classes at Herat University from the perspectives of five Afghan University English language instructors? (2) What strategies do the English language instructors implement in their large multi-level classes at Herat University to overcome the challenges? (3) What are the EFL students' attitudes of Herat University towards large multi-level classes?

\section{Literature Review}

This section mainly focuses on the study's theoretical framework, challenges of large class teaching, and the instructors' coping strategies.

\section{Research Theoretical Framework}

Kumaravadivelu's (2001) post-method pedagogy-parameters of particularities, practicality, and possibility - is the theoretical framework for the current study. In other words, considering the context of the study's uniqueness in terms of the socio-political and economic situation, this framework was found appropriate to guide this study. Although Kumaravadivelu's (2001) post-method pedagogy is limited to the teaching methodologies implemented in the language classes, it covers many other issues related to the context of teaching, such as the sociopolitical and economic situation of the country where teaching and learning take place. Kumaravadivelu (2001) stated that he used the term pedagogy to discuss the issues related to the classroom techniques, teaching materials, and curricular objectives and cover history-political and socio-cultural issues that influence L2 education. The parameter of particularity focuses on the pedagogy's relevancy to the teachers, learners, and the socio-cultural condition of the context where teaching and learning occur. The parameter of practicality refers to the teachers' perspectives and reflections on their teaching, resulting in creating practical strategies and teaching materials. Meanwhile, the parameter of possible states that the teachers' pedagogy should be in accordance with the context's sociopolitical condition. With that said, considering the Afghan context-specific needs and wants and a unique socio-political situation where teaching and learning have always been under its direct influence, Kumaravadivelu's (2001) threedimensional parameters are the most appropriate framework to guide the current study. 
Journal of Foreign Language Teaching and Learning

Volume 7, No. 1, January 2022

Available online at: https://journal.umy.ac.id/index.php/FTL/issue/view/833

e-ISSN: 2580-2070, p-ISSN: $2527-7650$

\section{Definition of a Large Class}

Although there is not a specific number stated by the TESOL organization to form a large class, there are recommendations from the Conference on College Composition and Communication (CCCC) that the number of students in a language class, specifically a writing class, should be ideally 15, and this number should not cross 20 students (Horning, 2007). A class is considered small if it is less than twenty students (Folmer-Annevelink, Doolaard, Mascareño, \& Bosker, 2010). However, this number is not that applicable to every context, in which dealing with large classes is at the center of teachers' discussions. Therefore, a teacher who has taught a class with 100 students may definitely consider a class with 50 students a small class. Similarly, a teacher who has taught classes, for example, made up of 20 students, may consider a class consisting of 50 students a large class (Todd, 2006). Considering a class as a large or small class depends on the teacher's teaching experience in different classes consisting of different numbers and the students' learning experiences studying in classes with different numbers.

According to Renaud, Tannenbaum, and Stantial (2007), the number of students in a class does not make a great difference as long as the teacher is fine with that number. Considering the existing literature in connection to large class size and the concept of what makes a class large or small, one can say that there is no specific number to tell teachers what a small or a large class is in different contexts. The notion and the concept of a large class depend on the teacher's and student's perception of a large class.

\section{Challenges of Teaching and Learning in Large Classes}

Issues related to large class teaching, such as class management, students' engagement, giving feedback to students and assessing students' homework assignments, and level-appropriate teaching materials, are discussed in this section.

Managing a large class, keeping students focused, and preventing distractions bring about a lot of workload and responsibilities to the instructor. According to Marzulina et al. (2021), a teacher should have certain skills to provide students with a positive and productive learning atmosphere. They added that effective English teaching does not occur in a poorly managed classroom. Further, the class size impacts the quality of teaching and may lead to the classroom management's success and/or failure. 
Journal of Foreign Language Teaching and Learning

Volume 7, No. 1, January 2022

Available online at: https://journal.umy.ac.id/index.php/FTL/issue/view/833

e-ISSN: 2580-2070, p-ISSN: 2527-7650

In a non-native English-speaking context where the instruction language should be English, having all students in a large class speaking English is challenging (Treko, 2013). Another critical issue that creates obstacles towards having a well-organized and well-managed classroom is the lack of space. In a class with 100 students, implementing group work activities and having all students sit in groups and monitor the groups is also challenging. Saying that, for example, it is even difficult for the teacher to walk and reach students sitting in the back rows (Brady, 2012).

Further, in a class with a large number of students, learners think they are ignored by the teacher, or the teacher does not notice them distracting the class and misbehaving; therefore, they are more intended to act disruptively compared to their peers in small classes (Finn, Pannozzo, \& Achilles, 2003).

Large classes also do not provide students enough opportunities to engage in class activities equally. Moreover, interactions between students are very limited, so that students do not have enough interactions with peers and their teachers. Considering the teacher's amount of time and the long list of the activities and the content she has to cover, there is less time to have students engaged in the class (Ozerk's, 2001). Similarly, Blatchford, Russell, Bassett, and Brown, Martin (2007) believe that interactions between teachers and students decrease significantly when the number of students increases.

Moreover, students can easily feel that the teacher has ignored them in large classes. In other words, in small classes, the teacher can quickly learn the students' names and reach them by their names, which undoubtedly positively affects students' participation. Unfortunately, in large classes, having all students engaged equally and helping them to realize that teacher knows them and pays attention to their needs and wants is not easy. Saying that students feel like they have been ignored by the teacher (Yazedjian \& Kolkhorst, 2007). In a similar vein, Harunasari and Halim (2019) stated that motivating and engaging students in large classes is a big challenge. The larger the class size is the more significant challenges the teachers struggle with.

The class size also limits the opportunities to provide students with immediate and adequate feedback (Bamba, 2012). Besides, Bamba (2012) added that there needs to be sufficient interaction between the teacher and students to find students' challenges and provide effective 
Journal of Foreign Language Teaching and Learning

Volume 7, No. 1, January 2022

Available online at: https://journal.umy.ac.id/index.php/FTL/issue/view/833

e-ISSN: 2580-2070, p-ISSN: 2527-7650

feedback. Similarly, Hedtrich and Graulich (2018) stated that providing individual, formative feedback to each student is challenging in large classes.

In addition, balancing the materials and bringing the teaching resources to meet the needs of all students equally and effectively is one of the issues in large classes. Considering a large population in each class, approximately 100-120 students, reaching each individual's interests and needs seems impossible (Hess, 2001).

Another important aspect of large class teaching is having students with different learning styles. Considering the learning styles variations and thinking of accommodating all those different learning styles to offer quality teaching is super challenging (Treko, 2013). Accordingly, Manrara (2007) affirmed that lack of resources is another issue teachers struggle with in large classes. Bringing teaching materials considering the student levels, needs, interests, and wants in a large class is not only a difficult task but also so much pressure on the teacher.

\section{Practical Strategies to Coping the Challenges of Large Classes}

Existing scholars have explored some effective strategies to cope with the challenges of large classes. Some strategies can help minimize the difficulties of managing a large class, students' engagement, giving and assessing feedback, and bringing teaching materials to address the student needs of different levels.

The more a teacher is educated in his/her teaching field, the better he/she can manage a large class. In other words, a teacher's friendly behavior with students and implementing effective practical teaching approaches considering the context's particularities help minimize the difficulties and issues behind classroom management (Finnan\& Shawn, 2010).

Bringing variation to teaching, such as examining and implementing different teaching strategies and activities, providing students with clear and understandable instructions, and making sure that students do the assigned tasks, is considered a helpful way to decrease classroom management-related issues (Tannenbaum \& Stantial, 2007).

Besides, reminding students of the importance of interactive-based activities to learning language, asking students to determine their groups probable before starting the semester to 
Journal of Foreign Language Teaching and Learning

Volume 7, No. 1, January 2022

Available online at: https://journal.umy.ac.id/index.php/FTL/issue/view/833

e-ISSN: 2580-2070, p-ISSN: 2527-7650

avoid wasting time, and doing peer work activities help increase student engagement in large classes (Herington \& Weaven, 2008).

Since large classes are mainly lecture-based, having discussions during the lecture helps keep students engaged and develops their motivation and understanding of the class's contents (Carpenter, 2006). Bringing level-appropriate teaching materials also helps to motivate students in large classes. Furthermore, it helps reduce the boredom of the advanced and low-level students (Roberts, 2007).

O'Leary (2013) believes that finding out students' needs through observation is helpful in large classes. In other words, a teacher may allocate a few sessions during the first few days of the semester observing students' performances and participation to assess his/her students' knowledge of the field, their level and learning styles, and their needs and interests.

\section{Method}

The study's design, context, participants, data collection, data analysis, and ethical considerations are discussed in this section.

\section{Study Design}

The current study attempts to explore the challenges of teaching large EFL classes at the English Department of Herat University from the perspectives of instructors and students. Further, this study investigated the instructors' practical strategies to overcome the counteracting challenges.

As discussed by Gay, Mills, and Airasian. (2012), "qualitative research is the collection, analysis, and interpretation of comprehensive narrative and visual (i.e., non-numerical) data to gain insights into a particular phenomenon of interest" (p. 7). Moreover, they mentioned that the individual's perspectives and ideas are essential for qualitative researchers. Therefore, going deep into individuals' experiences helps a qualitative researcher find answers to his/her research questions and reach a quality result. Since the current study aims to go deep into instructors' teaching experience in large classes at the English department and students' perspectives on learning in large classes, a qualitative research design is suitable for answering the research 
Journal of Foreign Language Teaching and Learning

Volume 7, No. 1, January 2022

Available online at: https://iournal.umy.ac.id/index.php/FTL/issue/view/833

e-ISSN: 2580-2070, p-ISSN: 2527-7650

questions.

\section{Participants}

The current study participants were the five English language instructors of Herat University who had experience teaching in large classes. Furthermore, ten current students of the English department of Herat University were also participants of the current study.

Table 1 .

Demographic Information of Interviewees (Instructors)

\begin{tabular}{llll}
\hline Interviewee & Gender & Teaching Experience & Educational Degree \\
\hline Ahmad & Male & Six years & MA TESOL \\
Nargis & Female & Nine years & MA TESOL \\
Mahmood & Male & Six years & MA TESOL \\
Wasal & Female & Nine years & MA TESOL \\
Fatemah & Female & Seven years & MA TESOL \\
\hline
\end{tabular}

Table 2.

Demographic Information of Interviewees (Students)

\begin{tabular}{lll}
\hline Interviewee & Gender & Educational Degree \\
\hline Arash & Male & Senior \\
Asma & Female & Junior \\
Fatemah & Female & Junior \\
Ahmad & Male & Senior \\
Mohammad & Male & Junior \\
Maryam & Female & Junior \\
Parwanah & Female & Senior \\
Neiman & Male & Junior \\
Shakib & Male & Senior \\
Nasimah & Female & Senior \\
\hline
\end{tabular}




\section{Data Sources}

Two data sources were face-to-face, semi-structured interviews with five instructors and ten EFL students in this study. The semi-structured interview protocol was chosen because of the freedom this type of question gives the researcher and the interviewees freedom to share their experiences and perspectives regarding the topic under investigation. Therefore, there were some follow-up questions for each main question as well. Galletta (2013) stated that semi-structured interviews give the researcher a great opportunity to have follow-up questions. Further, the data were collected following the study's theoretical framework - Kumaravadevilu post-method pedagogy. In other words, the history-political and socio-cultural of the Afghan teaching context were considered during the data collection.

\section{Data Analysis}

Considering the research questions and the theoretical framework, the data were analyzed thematically. The data were divided into two main categories: the data collected from the instructors' interviews and the data collected from the students' interviews. After dividing and separating the data collected from the interviews, the instructors' data were analyzed first. This data category was then divided into sub-categories, considering the research questions, the study's theoretical framework, and the study's literature review. Following the study's theoretical framework - Kumaravadevilu post-method pedagogy, the teaching pedagogies and the impact of the socio-economical context of teaching were considered while generating the themes. The data were presented in a narrative format, where the researchers wanted to go more in-depth to the issues of large class teaching and the instructors' coping strategies. According to Bazeley (2013), coding and thematic analysis of the data in qualitative research studies help the researchers reach the major aspects of their collected data.

Similarly, the same procedure was undertaken to analyze the students' interview data. With that in mind, the data collected from the ten interviewed students were divided into seven main themes. The students' perspectives on each theme were analyzed, interpreted, and discussed. 
Journal of Foreign Language Teaching and Learning

Volume 7, No. 1, January 2022

Available online at: https://journal.umy.ac.id/index.php/FTL/issue/view/833

e-ISSN: 2580-2070, p-ISSN: 2527-7650

\section{Ethical Considerations}

Each participant was provided with a pseudonym by the participant himself/herself. Moreover, all the recordings were saved in a password-protected folder on the researchers' laptops.

\section{Findings}

Some major themes that emerged from the interviews considering the research questions and the theoretical framework are discussed in this section:

\section{Large Class Teaching from the Interviewed Instructors' Perspectives}

Table 3.

\begin{tabular}{llc}
\multicolumn{4}{c}{ Instructors' Interviews Data Major Themes } \\
\hline
\end{tabular}

Reaching Students' Needs and Wants. One of the most critical aspects of teaching is understanding students' needs and providing teaching accordingly. The interviewed participants emphasized that students needed to know about their weaknesses and strengths to identify them and work accordingly. The findings also revealed that a teacher of a large class could not assess students' homework assignments and provide them with detailed and effective feedback. It was challenging for the teachers not only to provide students with feedback on their homework assignments that were but also to provide students with in-class comments was challenging. For 
Journal of Foreign Language Teaching and Learning

Volume 7, No. 1, January 2022

Available online at: https://journal.umy.ac.id/index.php/FTL/issue/view/833

e-ISSN: 2580-2070, p-ISSN: 2527-7650

example, in a class with 100 students, listening to each of them, addressing their weaknesses and strengths, and helping them to improve is impossible. Some students thought that the teacher ignored them; however, it was not valid. The fact is that the teacher could not address them all equally. The teacher participants of the study believed that peer feedback was a significantly helpful strategy in large classes. In other words, the teacher participants stated that they allocated at least ten minutes asking students to exchange their homework assignments and provide one another with feedback.

Detecting Plagiarism. According to Mahmood, one of the interviewed participants, who has been teaching several different courses for the last six years, he considered observing academic integrity challenging in large classes in an Afghan context. He also mentioned that in a class of 120 students, when the teacher assigned them [students] to do a paper, they could easily copy from sources outside the class and from their peers. The instructors did not have access to the databases to find previous year's student papers or machines to detect plagiarism.

Mahmood said that he was super sensitive about plagiarism, and it made him badly disappointed to catch students committing plagiarism. At the same time, he felt it was his responsibility to prevent plagiarism. Other participants stated that they tried to add the students' major assignments in their databases to prevent plagiarism. They believed that the only way to prevent plagiarism is having access to plagiarism detecting software.

Implementing Effective Teaching Approaches in Large Classes. The findings indicated that studying and learning about effective approaches to teaching was easy, but when it came to practicing these approaches to teaching effectively, the real struggle started. The teacher knew that it is more effective to teach a language through student-centered approaches. However, the fact is that when it came to implementing these techniques, the context's particular needs limited the teacher's freedom to implement what she considered effective.

On the other hand, other interviewed participants thought that lecture-based language teaching in large classes saved time and helped the teachers have more control over their class.

Workload and Appropriate Level of Teaching Materials in a Large Class. Teaching large classes is not the only concern of the teachers in the Afghan context, but the major concern is teaching many large classes, which puts many pressures on the teachers. In an Afghan context, a 
Journal of Foreign Language Teaching and Learning

Volume 7, No. 1, January 2022

Available online at: https://journal.umy.ac.id/index.php/FTL/issue/view/833

e-ISSN: 2580-2070, p-ISSN: 2527-7650

teacher teaches a minimum of 16 sessions per week. In other words, teaching at least four different courses in 4 large classes is what a teacher usually does at Herat University. Managing to offer quality teaching and reaching everything appropriately sometimes seem impossible. Two major things worried the teacher participants: providing teaching materials to satisfy the student needs of different levels and keeping students engaged and avoiding boredom in the class.

The major problem, according to the participants, was having multi-level students. There were beginner, intermediate, and advanced level students in a class, making the task of teaching super difficult. On the other hand, having access to resources and contextualized teaching materials to teach large classes with multi-level students was one of the challenges teachers struggle with. Fatemah stated that students of lower levels could not benefit from the class when she introduced advanced-level materials. She mentioned that she had students unfamiliar with English alphabets, let alone digest advanced-level teaching materials. When she brought low-level teaching materials, the advanced level students got bored and preferred not to stay in the class.

The teacher participants also stated that the instructors should design their own contextualized and level-appropriate materials considering their students' needs and wants.

\section{Interviewed Students' Reported Experiences with Learning in Large English Classes}

The major findings of the interviews with students are discussed in this section.

Table 4.

Students' Interviews Data Major Themes

\begin{tabular}{lll}
\hline \multicolumn{1}{c}{ Major Themes } & $\begin{array}{l}\text { Number } \begin{array}{c}\text { of } \\
\text { Participants Who } \\
\text { Experienced This }\end{array} \\
\end{array}$ & Percentage \\
\hline 1. Large classes are not productive. & Eight participants & $80 \%$ \\
2. Students are passive in large classes. & Nine participants & $90 \%$ \\
3. Students are ignored in large classes. & Six participants & $60 \%$ \\
4. The teaching materials and students & Eight participants & $80 \%$ \\
& of different levels in large classes & $100 \%$ \\
5. Lack of feedback and comments in & Ten participants & \\
\hline
\end{tabular}


Journal of Foreign Language Teaching and Learning

Volume 7, No. 1, January 2022

Available online at: https://journal.umy.ac.id/index.php/FTL/issue/view/833

e-ISSN: 2580-2070, p-ISSN: 2527-7650

Large Classes Are Not Productive. According to the students, large classes tended to be more lecture-based than small classes. The classes were primarily lecture-based, where students were passive and sitting and listening to the teacher. Therefore, they did not practice what they studied in theory to produce content. Lack of time, teacher's availability, and feedback could be among the challenges limiting the productivity of large classes.

At this university, each class lasted about 50 minutes. In this short period, the teacher could not even ensure the presence of all the students, let alone engage them with activities and exercises where they could produce new things using the theories they have studied, according to the participants. One of the interviewed participants also mentioned that when she was assigned to do a particular paper, she did not find the teacher to talk to him/her about how to do that particular assignment. For example, the written instructions were not always enough. She added, "I go to the office to ask my teacher questions about the assignment, but he is not there; I go many times, but the teacher is in the class." In this case, although students were provided with instruction, they did not always find them clear enough. Therefore, they needed to have face-to-face meetings with the teachers to ensure they were going the right way.

Moreover, in large classes, students did not receive feedback from their teachers. Lack of feedback lowered the student's and the classes' productivity. Saying that Arash mentioned that in one of his classes, he was supposed to do a final paper of ten pages. He submitted the first draft, but the teacher did not give him feedback. Then, without specifying what changes they had to make to their papers, the teacher told the class to submit a second draft. Students, realizing that the teacher did not check the papers, did not work on their second draft. Therefore, they submitted the draft the same one they had submitted at first.

Students Are Passive in Large Classes. The findings indicated that the teachers preferred lecture-based teaching in large classes because it saved time and prevented noises and distractions. All the interviewed students mentioned that they found studying in large classes boring because they passively received the knowledge. They did not find themselves engaged in the process of learning.

Mohammad mentioned that he did not remember when he was engaged in the learning process. He stated that most of his classmates sitting in the back were not involved in the learning 
Journal of Foreign Language Teaching and Learning

Volume 7, No. 1, January 2022

Available online at: https://journal.umy.ac.id/index.php/FTL/issue/view/833

e-ISSN: 2580-2070, p-ISSN: 2527-7650

process. In other words, not all the students were included in the class discussions and were not engaged throughout the learning process. He added, "students who sit in the back of the class do not listen to the teacher; they are busy with their mobiles, and they do not pay attention to the teacher, and the teacher does not come to the back of the class."

Moreover, students need to be encouraged by the teacher, they need to share their works with others, and they want others to see what they did. Unfortunately, when they saw that nobody, including the teacher, knew what and how they had performed and they were not praised for the quality work they offered, they started becoming demotivated, according to the participants.

Students were also not used to studying in a co-education setting. Upon completing high school, students first experienced studying in a co-education context, creating issues in terms of engagement, particularly for girls, who were coming out of a traditional-based dominated society. It is where interactions between men and women outside the home are super limited. It is especially apparent in large classes, where it takes years for students to get to know one another and feel comfortable studying under the same celling with the opposite gender.

Students Are Ignored in Large Classes. Parwanah mentioned that "the teachers only teach; they do not know about our problems and difficulties. They teach, but they do not know that the lesson is difficult for most students, and it is easy for a few." In this case, an emotional relationship between students and teachers is important to encourage students to work hard and value learning.

It is not only about knowing students by their names but understanding their situation is also essential. Ahmad, one of the interviewed students, mentioned that he struggled with many issues, such as family problems. He thought that these struggles had a very negative impact on his learning process. It sometimes got that serious that Ahmad could not focus on his studies. He mentioned that teachers got angry at him for not doing what the courses required, but they never asked him why he could not improve and concentrate on his lessons. According to the interviewed students, teachers in large classes tried to complete their syllabuses and examinations. Students were ignored, and they were sacrificed.

Teaching Materials and Students of Different Levels in Large Classes. One of the main concerns of students, who were interviewed, was the difficulty level of the teaching materials. For 
Journal of Foreign Language Teaching and Learning

Volume 7, No. 1, January 2022

Available online at: https://iournal.umy.ac.id/index.php/FTL/issue/view/833

e-ISSN: 2580-2070, p-ISSN: 2527-7650

example, Parwanah considered her level of English proficiency low; she mentioned, "My level of English language proficiency is very low compared to most of my classmates. I struggle a lot to do the assignments and follow the teachers' lectures" (Translated from Persian to English). She thought that coming and studying the English language and literature was very difficult for students who had never been exposed to English in their lives. She struggled with a wide range of issues in her classes. She added that the teaching materials were much higher than her level of language proficiency.

On the other side, there were students whose language proficiency was higher, and they thought that they did not benefit from the classes as much as they expected. For example, Maryam, who considered herself advanced, thought teachers introduced low-level teaching materials. She mentioned, "the teachers have to bring low-level teaching materials because most of the students are considered low level, while those advanced students do not really benefit from the low-level teaching materials, and the class is not that interesting."

Lack of Feedback and Comments in Large Classes. Ahmad mentioned that they were given homework assignments, but they never received their teachers' feedback and comments. For example, he talked about one of the courses' major assignments. The teacher told them that he would provide them with feedback before submitting their final draft to be graded. However, students submitted the final draft without making any revisions to that. The reason was that the teacher did not get to provide them with feedback on their first draft.

Furthermore, receiving feedback on their [students] written homework assignments was not the only area where the teacher could not comment accordingly. Nasimah mentioned that the teacher assigned them an in-class group presentation, but a few students were given the opportunity to come in front of the class and present their projects. The semester ended, and the rest of the students did not present their projects. On the other hand, those few groups who gave presentations did not receive any comments from the teacher. The reason was that there was not enough time for the teacher to specify his/her students' weaknesses and strengths. The teacher tried to give a chance to a larger number of students to take part and present their final projects, yet she failed to finish them all during the semester. 
Journal of Foreign Language Teaching and Learning

Volume 7, No. 1, January 2022

Available online at: https://journal.umy.ac.id/index.php/FTL/issue/view/833

e-ISSN: 2580-2070, p-ISSN: 2527-7650

According to the interviewed students, with some courses, it was okay if the teachers did not get to give them feedback. However, they needed to know about their performances in other courses such as writing classes. Arash stated that they did many papers in their academic writing course, but they never received any comments from their writing teacher. Therefore, they had no ideas about how they had performed. They [students] even did not know whether they had improved with all the hard work and efforts they had put in or not.

In conclusion, students need to know about their progress, and the person who can help them is the teacher. Students did not receive comments and feedback on their academic performances in large classes, especially during the semester. Both teachers and the interviewed students stated that large class teaching limited interactions between teacher and students and received feedback and comments from the teachers.

\section{Discussion and Conclusion}

One of the most challenging areas in large classes was reaching each student to meet their needs and wants. In a class made up of 100 students, a teacher could not know his/her students well, particularly, what they needed, what they wanted, and what ways and methods of learning work well for them. On the other hand, students in large classes did not participate in-class activities. There were different factors why students were not willing to take an active part in large classes: a large number of students created the fear of embarrassment in case of making mistakes among students. In a similar vein, Harunasari and Halim (2019) asserted that motivating and engaging students in large classes is a big challenge. The larger the class size is, the more significant challenges the teachers struggle with.

The findings also indicated that teaching was not about covering a few textbook pages and transferring them to students. Teaching has to be in accordance with the students' needs, wants, interests, and learning styles. According to Nasimah, one of the interviewed teachers, it was almost impossible for the teacher to meet the aspects mentioned earlier of teaching in large classes. A teacher hardly got to know some basic things about his or her students. In addition, Mohammad mentioned that it was essential for him to know his students by their names. He thought it helped him build a better relationship with his students and helped them realize that 
Journal of Foreign Language Teaching and Learning

Volume 7, No. 1, January 2022

Available online at: https://journal.umy.ac.id/index.php/FTL/issue/view/833

e-ISSN: 2580-2070, p-ISSN: 2527-7650

the teacher cared about them. In this regard, Kearney (2013) emphasized the importance of understanding students and understanding how they learned. She believes that it can be achieved when the teacher explores her students and provide them with what they want. Therefore, allocating the first few class sessions to observe students' academic performances and see how they progress throughout the learning process plays a vital role in teaching the class effectively.

According to the participants, feedback and comments were the most critical issue behind large class teaching and learning. Hence, large class teaching limited teachers to provide their students with feedback on their oral and written homework assignments. Similarly, Hedtrich and Graulich (2018) stated that providing individual, formative feedback to each student is challenging in large classes. Ahmad also mentioned that he tried to provide his students with general feedback on their oral in-class production but not on their written homework assignments. Concerning this, the existing literature and the research conducted on large class teaching indicated that peer feedback is one of the most helpful ways of helping students to get an idea of their homework assignments and performances. Meanwhile, the class size limits the opportunities to provide students with immediate and adequate feedback (Bamba, 2012).

Moreover, Bamba (2012) added that there need to be sufficient interactions between the teacher and students to find students' difficulties to address those issues and provide effective feedback. Besides, Yang, Badger, and Yu's (2006) study showed that peer feedback helps students realize their strengths and weaknesses and develops a sense of responsibility and autonomy among students. In other words, students feel responsible before one another, and they realize the importance of sharing their knowledge and understanding through working cooperatively.

\section{Further Research Directions}

This exploratory study looked at different aspects of large class teaching and learning. More research studies can be conducted, considering one specific element: large-class feedback. Further, the current study is qualitative and does not let the data be generalized. Further studies can be carried out through a different research design, such as quantitative and or mixed methods, where more participants can be involved. Moreover, following a quantitative research design lets the data be generalized over a larger context. In addition, a comparison and contrast 
Journal of Foreign Language Teaching and Learning

Volume 7, No. 1, January 2022

Available online at: https://journal.umy.ac.id/index.php/FTL/issue/view/833

e-ISSN: 2580-2070, p-ISSN: $2527-7650$

study can also be conducted on large class teaching. The researchers can choose two different contexts (universities) and explore the large class teaching challenges.

\section{Implications of the Study for Teachers and Administrators in Higher Education}

The current study's findings showed many challenges behind teaching and learning English in large classes in an Afghan context. Large class teaching limited the effectiveness of teaching and learning. Moreover, the teachers of large classes struggled with different challenges from management to assessment and reaching students' needs and want.

Furthermore, the results of this study revealed that the number of students increased at Herat University, while the resources and the number of facilities remained the same. Therefore, immediate attention of the administration in higher education is needed to take the challenges of teaching large classes seriously. They are responsible for increasing the facilities and decreasing the number of students in each class in general. In particular, English language classes need to get smaller to help teachers offer quality teaching and ensure the effectiveness of teaching and learning.

Administrators in higher education should also support teachers and provide them with workshops and seminars to develop their teaching skills. Capacity-building programs help teachers to become more equipped with new teaching strategies.

On the other hand, there are very limited research studies on large class teaching and learning in Afghan contexts. Therefore, more research is needed to investigate different aspects of large class teaching and explore coping strategies.

At the same time, teachers are responsible for updating their knowledge and understanding of teaching and learning. Language changes over time, needs and wants are changing as well. Therefore, as the needs and wants change, teaching methods change. Teachers are supposed to share their experiences of large classes with their colleagues. Specifically, new teachers who are not experienced in teaching large classes need to develop their understanding of large class teaching before starting the actual teaching. 


\section{References}

Bamba, M. (2012). Seeking effective approaches to teaching large EFL classes in the Ivory Coast (master's thesis). Indiana University of Pennsylvania, Indiana, Pennsylvania.

Bazeley, P. (2013). Qualitative data analysis: Practical strategies. Sage.

Blatchford, P., Russell, A., Bassett, P., Brown, P., \& Martin, C. (2007). The effects of class size on the teaching of pupils aged 7-11 years. School Effectiveness and School Improvement, 18(2), 147-172. https://doi.org/10.1080/09243450601058675

Brady, B. (2012). Managing assessment in large EFL classes. The Cambridge Guide to Second Language Assessment, 291-298.

Carpenter, J. M. (2006). Effective teaching methods for large classes. Journal of Family E⿱ Consumer Sciences Education, 24(2), 13-23.

Finnan, R., \& Shaw, D. (2010). Teaching large classes I-classroom management. Retrieved from http://people.math.sfu.ca/ ${ }^{\sim}$ vjungic/classroom_management.pdf

Finn, J. D., Pannozzo, G. M., \& Achilles, C. M. (2003). The "why's" of class size: Student behavior in small classes. Review of Educational Research, 73(3), 321-368. https://doi.org/10.3102\%2F00346543073003321

Folmer-Annevelink, E., Doolaard, S., Mascareño, M., \& Bosker, R. J. (2010). Class size effects on the number and types of student-teacher interactions in primary classrooms. The Journal of Classroom Interaction, 30-38.

Galletta, A. (2013). Mastering the semi-structured interview and beyond: From research design to analysis and publication. NYU Press.

Gay, L., Mills, G., \& Airasian, P. (2012). Overview of qualitative research. Educational research: Competencies for analysis and applications. Pearson Education Inc (10th ed).

Harunasari, S. Y., \& Halim, N. (2019). Digital backchannel: Promoting students' engagement in EFL large class. International Journal of Emerging Technology in Learning, 14(7), 163-178. https://www.learntechlib.org/p/208519/

Hedtrich, S., \& Graulich, N. (2018). Using software tools to provide students in large classes with individualized formative feedback. Journal of Chemical Education, 95(12), 2263-2267. https://doi.org/10.1021/acs.jchemed.8b00173

Herington, C., \& Weaven, S. (2008). Action research and reflection on students approaches to learning in large first year university classes. The Australian Educational Researcher, 35(3), 111-134. https://doi.org/10.1007/BF03246292

Hess, N. (2001). Teaching large multi-level classes. Cambridge University Press. 
Horning, A. (2007). The definitive article on class size. Journal of the Council of Wring Program Administrators, 31(1/2), 11-34.

Kearney, E. M. (2013). On becoming a teacher. Springer Science \& Business Media.

Kumaravadivelu, B. (2001). Toward a post method pedagogy. TESOL Quarterly, 35(4), 537-560. https://doi.org/10.2307/3588427

Manrara, M. A. (2007). Explaining the effects of class size on faculty and students (doctoral dissertation). Florida International University.

Marzulina, L., Erlina, D., Holandyah, M., Harto, K., Desvitasari, D., \& Angreini, D. (2021). English Teachers' Strategies in Managing Large Classes: A Case Study. | IRJE| Indonesian Research Journal in Education |, 5(2), 417-43. https://doi.org/10.22437/irje.v5i2.15705

O'Leary, M. (2013). Classroom observation: A guide to the effective observation of teaching and learning. Routledge.

Ozerk, K. (2001). Teacher-student verbal interaction and questioning, class size and bilingual students' academic performance. Scandinavian Journal of Educational Research, 45(4), 353-366. https://doi.org/10.1080/00313830120096761

Renaud, S., Tannenbaum, E., \& Stantial, P. (2007). Student-centered teaching in large classes with limited resources. English Teaching Forum, 45 (3), 12- 17.

Roberts, M. (2007). Teaching in the multi-level classroom. New York: Pearson Education.

Sarwar, Z. (2001). Adapting individualization techniques for large classes. In D. Hall \& A. Hewings (Eds.), Innovation in English language teaching: A reader, 127-136.

Shamin, F. (1993). Teacher-learner behaviour and classroom processes in large ESL classes in Pakistan (doctoral dissertation). The University of Leeds.

Todd, R. W. (2006). Why investigate large classes. REFLections, 9(Special), 1-12.

Treko, N. (2013). The big challenge: Teaching large multi-level classes. Academic Journal of Interdisciplinary Studies, 2(4), 243. http://dx.doi.org/10.5901/ajis.2012.v2n4p243

Yang, M., Badger, R., \& Yu, Z. (2006). A comparative study of peer and teacher feedback in a Chinese EFL writing class. Journal of Second Language Writing, 15(3), 179-200. https://doi.org/10.1016/j.jslw.2006.09.004

Yazedjian, A., \& Kolkhorst, B. B. (2007). Implementing small-group activities in large lecture classes. College Teaching, 55(4), 164-169. https://doi.org/10.3200/CTCH.55.4.164-169 
Journal of Foreign Language Teaching and Learning

Volume 7, No. 1, January 2022

Available online at: https://journal.umy.ac.id/index.php/FTL/issue/view/833

e-ISSN: 2580-2070, p-ISSN: 2527-7650

Yu, S., \& Lee, I. (2016). Peer feedback in second language writing (2005-2014). Language

Teaching, 49(4), 461-493. https://doi.org/10.1017/S0261444816000161 


\section{Appendix A}

\section{Interview Protocol for the Instructors of the English department of Herat University}

The following open-ended questions are developed for data collection for a qualitative inquiry entitled 'Teachers' and Students' Attitudes Towards English Large Classes at Herat University". There are some follow-up questions if need be. The point to be mentioned is that the interview lasts for 40 to 50 minutes.

1. Would you please briefly introduce yourself?

a. How long have you been teaching?

b. What kind of courses have you taught?

2. How many students are there in your classes?

a. Do you think your classes are large or small? Why?

3. What kind of teaching methodologies do you implement in your classes?

a. Particularly those classes that you think are large?

4. Do you think teaching in large classes is difficult or easy?

5. What are some of the challenges you have struggled with in your large classes?

6. What are some of your coping strategies?

a. Do you think you can overcome the challenges you encounter in your large classes?

7. What is and/or are some good things about teaching large classes?

8. Do you think teaching in large classes is effective?

a. Do your students benefit from you?

b. Do all of your students benefit from the teaching materials you provide them?

If there is anything you want to add to your words, please share them?

\section{Appendix B}

\section{Interview Protocol for Students of the English Department of Herat University}

The following open-ended questions are developed for data collection for a qualitative inquiry entitled 'Teachers' and Students' Attitudes Towards English Large Classes at Herat University". There are some follow-up questions if need be. The point to be mentioned is that the interview lasts for 40 to 50 minutes.

1. Would you please introduce yourself?

a. How long have you been studying English?

b. Where did you start learning English before coming to the university? If any?

c. What made you decide to major in English language and literature?

2. How many students are there in your class?

3. What do you like the most about your class?

4. Do you consider your class large or small?

5. What kind of teaching methodologies do your teachers implement in your classes?

6. Do your teachers know you by your name? 
Journal of Foreign Language Teaching and Learning

Volume 7, No. 1, January 2022

Available online at: https://journal.umy.ac.id/index.php/FTL/issue/view/833

e-ISSN: 2580-2070, p-ISSN: 2527-7650

7. Do you get to talk to your teacher outside the class?

8. Do you receive feedback on your assignments from your teachers?

9. Do you get encouraging words from your teachers?

Do you get to share your personal problems that affect your learning process with your teacher? 